\title{
Entrepreneurial training for Human Resource Practitioners and potential services rendered to small enterprises
}

\author{
R. van der Walt \\ Department of Human Resources Management, University of Pretoria \\ ruan.vanderwalt@up.ac.za* \\ S. J. van der Walt \\ Consultant
}

*To whom all correspondence should be addressed

\begin{abstract}
This article examines to what extent current South African university courses/programmes in Human Resources Management and Industrial Psychology prepare students for a career in entrepreneurship. It is argued that human resources practitioners have much to offer in the line of services and advice to small enterprises on how to succeed. The data of the survey are analysed through a qualitative approach. The findings indicate that entrepreneurship training currently receives limited attention in the training of human resources practitioners and industrial psychologists.
\end{abstract}

Key words and phrases: entrepreneurial education, human resources management, industrial psychology

\section{Introduction}

Depending on the definition used, the unemployment rate in South Africa is estimated to be between 29.5 percent and 41.5 percent (Barker, 2003:209). The 2007 Labour Force Survey of Statistics South Africa (StatsSA) puts the unemployment rate at 25.5 percent in March 2007 (StatsSA, 2007). In view of such disturbing figures it can therefore be argued that unemployment is one of the biggest challenges facing South Africa.

In many parts of the world it has been found that small enterprises and the informal sector constitute a significant part of the total employment or have significantly contributed to the increase in total employment opportunities in recent years (Liedholm, 2002:227-242). It is estimated by the South African Small Business Annual Summit that the country has between 2.8 and 2.5 million small, micro and medium enterprises (SMMEs) (SABG 2006/2007:172). Of great concern is that SMMEs in South Africa have a failure rate of between 70 percent and 80 percent (Van Eeden, Viviers \& Venter, 2003:13).

In South Africa one often reads that many of our economic problems such as unemployment could be alleviated by the development of SMMEs and entrepreneurship (Luiz, 2002:53). In view of this it would be sensible for tertiary training institutions to play a significant role in encouraging and training students for entrepreneurship. Many tertiary institutions do in fact have programmes or courses in entrepreneurship. Duncan Randall of First National Bank's Progress Fund is of the opinion that young entrepreneurs who "make it" are typically in their late 20s, have a tertiary qualification and have work 
experience in either the private sector or in semi-government organisations (Christianson, 2005:12).

This article advocates that tertiary training institutions should seriously encourage entrepreneurship and self-employment career opportunities in all academic disciplines being taught, be they engineering science, agricultural science, the arts, social science, educational science or any other programmes offered. This need is even advocated for music students, with the plea that entrepreneurship training should "strike a chord" with musicians to develop their own entrepreneurial potential (Miller, 2007:20). Entrepreneurial training of human resources managers could lead to an important role as a collaborative partner in assisting founders of economically sound new ventures (Klofsten, 2005:105).

The purpose of the present research was to establish whether the programmes or courses in Human Resources Management and Industrial Psychology taught at South African tertiary institutions are also aimed at entrepreneurship and self-employment, and whether the programmes lead to career options in entrepreneurship and self-employment for students. Such training would serve a double purpose for human resources managers: not only would they become more independent and entrepreneurial, but they could simultaneously assist SMMEs in their entrepreneurial ventures, not only in human resources matters but also entrepreneurial achievements. Developing professionals to become entrepreneurs could encourage them to become more proactive in determining their own destinies (Miller, 2007:20).

Research data were collected by means of personal interviews and by examining the web pages of these tertiary training institutions to establish firstly whether the training programmes had entrepreneurship and self-employment as one of their goals, and secondly whether the programmes made students aware of career options in entrepreneurship and self-employment.

Given South Africa's current situation, it should be clear that all attempts to promote and enhance entrepreneurship and small business ownership should be welcomed and actively encouraged.

\section{Literature review}

Barker (2003:200-201) points out the following reasons why job creation is of the utmost importance to South Africa: unemployment has grave consequences for any country; employment is essential for economic growth and higher standards of living; greater job creation will also address other important social priorities; affirmative action policies are much more difficult to implement successfully without economic growth; unemployment confines people to poverty, especially in rural areas; and high unemployment is having a serious effect on perceptions of the success of the market economy. In essence the proactive proliferation of SMMEs leads to the creation of jobs, influencing the generation of wealth and social stability (Ladzani \& Van Vuuren, 2002:154; Van Eeden et al., 2003:14). 
Although somewhat dated, a study by Moolman in 1984 (Du Plessis, 1996:163) examined the importance of SMMEs in different parts of the world and found that SMMEs represented between 82 percent and 99.8 percent of the total number of enterprises of the various countries; SMMEs provided employment opportunities for between 21 percent and 66 percent of the total private-sector labour force; and their contribution to the total turnover in these countries varied from 19 percent to 73 percent.

SMMEs have an indisputable economic and social function in any free-market economy. In South Africa SMMEs are regarded as one of the major instruments for creating jobs, stimulating growth and ensuring equality (Ladzani \& Van Vuuren, 2002:154).

It has been pointed out in the government's Growth, Employment and Redistribution (GEAR) policy that the SMME sector is severely underdeveloped in South Africa (RSA, 1996:13). The promotion of this sector is a key element in the government strategy for employment creation (RSA, 1998: par.2.4.2.3), and strategies such as improving access to land, finance and support services such as human resources management advice are proposed.

As a developing country, South Africa faces one of the same dilemmas that confront other developing countries. This is that South Africa simply does not have a sufficient number of entrepreneurs and has too few people with entrepreneurial qualities and attributes (Pahn, 1993:8). These deficiencies lead to low economic performance, resulting in few succeeding as entrepreneurs. Van Aardt and Van Aardt (1997:3) point out that generally South Africans are not socially encouraged or educated to become entrepreneurs. They traditionally enter the labour market as employees and become consumers of existing jobs, rather than creating new jobs through their entrepreneurial efforts. An appropriate route to embarking on full-time entrepreneurship would be to work as an employee in a successful enterprise for a period to gain experience and develop entrepreneurial ideas (Van Aardt \& Van Aardt (1997:3). This route could prevent failures, as many young, enthusiastic entrepreneurs are soon disillusioned when new ventures fail, discovering that technical knowledge alone does not guarantee successful enterprise (Tchouvakhina, 2004:233).

Terblanche (2007:7) points out that small business development is not automatically the solution to joblessness in South Africa. He writes that to advise the unemployed that they must start their own business is cruel, as it is many times more difficult to start your own business than to find a job. Terblanche (2007:7) uses the case of the failure of the ChopChop fried-chicken street-vendor franchise. This was a venture in which the entrepreneur/franchisee set up a portable griller in the street for frying chicken. This author suggests that one of the reasons for the high failure rate by most start-up projects is recruiting the wrong candidates. Terblanche (2007:7) quotes Ivor Blumenthal, the CEO of the Service Seta and custodian of the New Venture Creation Learnership, who laments the notion that the youth are the best entrepreneurs, because they often fail in their venture because of a lack of experience. It is the experienced older entrepreneurs who understand business finance who are more successful. 
Von Broembsen (2006:13) writes that the potential for tertiary educated adults to create employment is two-and-a-half times greater than for adults who have finished only secondary school. It has been shown that becoming an employee for a period of time to gain experience and develop entrepreneurial ideas is an excellent route to full-time entrepreneurship (Von Broembsen, 2006:13). It is interesting, however, to note that in a study at macro level it was found that a higher level of education in a country is accompanied by a lower self-employment rate (Uhlander \& Thurik, 2007).

The findings of the 2005 Global Entrepreneurship Monitor (GEM) study paint a dismal picture of the South African position (Von Broembsen, Wood \& Herrington, 2005). GEM argues that South Africa's overall entrepreneurship ranking has dropped from 20th position in 2004 to 25th out of 35 countries in 2005 (Von Broembsen et al, 2005:17). The country's early-stage entrepreneurial activity measure has also declined from 5.4 percent in 2004 to 5.1 percent in 2005 (Von Broembsen, 2006: 13).

In South Africa the importance of entrepreneurship has been widely recognised by government, which has therefore made major efforts to identify entrepreneurs, provide them with capital, stimulate their enterprise, support their development and generally make it easier for entrepreneurs to enter the business sector without unnecessary bureaucratic rules and regulations (ISEDS (Integrated Small-Enterprise Development Strategy), 2005). The government is fully aware that the development of entrepreneurship is an urgent prerequisite for increasing the standard of living and economic growth in South Africa (ISEDS, 2005).

Many emerging enterprises do not have the need for, or are often unable to, employ a full-time management specialist in the areas of marketing management, financial management, engineering management, information technology management and human resources management. This is precisely the situation that creates an opportunity for graduates in these disciplines to become entrepreneurs and provide services and products to other entrepreneurs and small enterprises.

\section{Services which human resources practitioners can provide to SMMEs}

Many entrepreneurs and owners of SMMEs are so focused on getting their enterprise off the ground and/or keeping their enterprise on track that "non-essential" aspects such as tax, sales promotion and employee matters are often neglected. Understandably, small businesses may not be able to afford full-time human resources staff, but the small business owner should consider obtaining the services of a human resources consultant occasionally or on a regular basis, depending on the business needs and affordability. As a result of misunderstandings and disputes, many entrepreneurs and SMMEs have learnt costly lessons at the Commission for Conciliation, Mediation and Arbitration (CCMA) and the Labour Court. Although many of these disputes have a labour relations colour, they have their roots in poor human resources practices (Simoncelli, 2007). Many of these disputes could have been avoided or dealt with inexpensively had a knowledgeable human resources practitioner been involved at an earlier stage or from the founding of the business. 
It has been indicated that many small enterprises fail due to poor management (Klofsten, 2005:105; Tchouvakhina, 2004:233; Van Eeden et al., 2003:13). It is therefore most important that small business owners obtain expert advice. Literature on the relationship between the entrepreneurial training of human resources managers and SMMEs seems to be almost non-existent. An exploratory, qualitative investigation (Zikmund, 2003:54-55) was conducted to investigate this phenomenon.

\section{Research methodology}

Two forms of data-gathering were conducted for this study, namely qualitative primary and secondary data analysis (Zikmund, 2003:63-64). The primary data were gathered by means of personal interviews with two human resources practitioners. The interviews are described in relation to applicable literature.

The secondary data were gathered by investigating the entrepreneurial education of Human Resource Management students in 23 tertiary institutions in South Africa. The data sources were academic departments where Human Resources Management and/or Industrial Psychology are taught at the 23 tertiary institutions. Through an examination of their respective web pages we attempted firstly to determine whether their academic programmes are aimed at not only employment in organisations but also self-employment through entrepreneurship, and secondly to establish what type of career opportunities the programmes are preparing students for.

The nature of the social phenomenon which is the object of this research project steered the researchers in the direction of qualitative analysis, particularly the approach advanced by Miles and Huberman $(1984 ; 1994)$. Miles and Huberman's view of qualitative analysis $(1984 ; 1994)$ is described by Punch as "tracing out lawful and stable relationships among social phenomena, based on the regularities and sequences that link these phenomena". This approach views data analysis as concurrent flows of activity: data collection, data reduction, data display and conclusion drawing/verification (Punch, 2005:197). Creswell (1998: 142-165) describes the process of qualitative data analysis and interpretation as a spiral image - a data analysis spiral.

\section{Results}

\section{Primary data interview results}

According to a personal communication with Mr J.L. van der Walt (2007), former HR manager and regional chairperson of the Institute of Personnel Management, and a personal communication with Mr F. Simoncelli (2007), human resources and labour relations consultant, the first major move of human resources practitioners into the world of entrepreneurship in South Africa occurred in the late 1970s and 1980s, when some human resources practitioners left the corporate world to become so-called independent labour relations and personnel consultants. This phenomenon was triggered by events in 
the labour relations arena and changes in labour-related legislation (Finnemore, 2002:1932).

Traditionally the aim of the education and training of the personnel practitioner, the manpower practitioner, human resources practitioner, people management practitioner and industrial psychologist was directed at the delivery of specialised services to organisations, particularly the large corporate organisations which employed hundreds of employees. This was also the situation in South African organisations. (Grobler, Wärnich, Carrell, Elbert \& Hatfield, 2006:2-38); Nel, Van Dyk, Haasbroek, Schultz, Sono \& Werner, 2004:3-29).

Following the traditional career path, most students in the human resources management field envisaged their careers developing in a corporate environment, although some entered directly into consultancy firms (Van der Walt, 2007; Simoncelli, 2007). However, as the best financial rewards and development opportunities were perceived to be offered in the corporate world, the majority of human resources practitioners worked and made their contribution to progress and success in that sector (Van der Walt, 2007; Simoncelli, 2007). It is important to bear in mind that many human resources practitioners and consultants were still employees, although some had attained very senior positions (Van der Walt, 2007; Simoncelli, 2007).

The move by human resources practitioners to establishing themselves as independent consultants meant that they now had to start thinking as entrepreneurs or small-business owners whose success depended on the delivery of satisfactory services to clients. Some practitioners were successful in making this transition to entrepreneurship, while others who could not make this difficult transition have had to fall back to employment in the private or public sector (Simoncelli, 2007).

It is in our view surprising that very few, if any, of the educational and training institutions took serious note of this phenomenon and adapted the aim and the curricula of the human resources and labour relations management courses they offered to equip their students with the skills needed to become human resources entrepreneurs, and not only employees in the human resources sector of an enterprise. By their failing to prepare their students for this alternative career path in human resources management, valuable human capital has over the years been under-utilised and a possible contribution to the total South African economy substantially reduced. For instance, human resources management consultants could offer essential human resources services to SMMEs and other entrepreneurs who lack the knowledge and skills to efficiently handle organisational problems. This would greatly contribute to the success of SMMEs as employment creators in South Africa. If South African tertiary institutions fail to react and make these changes they will be ignoring a worldwide trend of the past 35 years to introduce entrepreneurship in universities (Dana, 1993:70).

Williamson (2000:28) used institutional theory to develop a strategic model for small business human resources recruitment. This author introduced the notion of employer legitimacy, which is defined as a generalised perception or assumption held by job 
applicants that an organisation is a desirable, proper and appropriate employer, given the system of norms, values, beliefs and definitions that exist within an industry. Williamson (2008:28) posits that to the extent that an organisation's recruitment procedures and other human resources policies are viewed as proper and appropriate by potential job applicants, that organisation will be seen as a legitimate employer. This is where human resources practitioners can make a contribution.

In view of the contribution that human resources practitioners could make to the success of SMMEs, and the fact that tertiary educational institutions do not (but should) inculcate entrepreneurial spirit in all their students, the study outlined below was conducted.

\section{Secondary data analysis}

As a departure point, the study included all 23 institutions of higher learning listed in the diaries published by the Purchasing Consortium Southern Africa (PURCO), and each institution was regarded as a separate case and given a number. Where possible, the applicable sections of the web page of each institution's relevant department were printed for later examination and reduction of data. The web pages of two cases could not be accessed, possibly due to technical problems at the time. This left 21 cases for examination.

To meet one of the criteria of good qualitative research, namely credibility, through triangulation of multiple sources of data as suggested by Lincoln and Guba (1985:20), attempts were made to find additional alternative sources of information. The South African Qualification Authority's (SAQA) information on Human Resources Management qualifications was therefore also examined. Unfortunately, this source did not reveal any useful information for purposes of the current study.

The data reduction activity of the qualitative analysis process refers to selecting and transforming the "raw" data from written field notes or other sources of data that could be utilised for research purposes (Miles \& Huberman, 1984:36). Data are further reduced through focusing and bounding the research, which generally consists of building a conceptual framework, formulating research questions, sampling and instrumentation (Miles \& Huberman, 1984:36).

A conceptual framework explains either graphically or in narrative form the main dimensions to be studied - the key factors or variables and the presumed relationships. A framework can be rudimentary or elaborate, theory-driven or commonsensical, descriptive or causal. Using the method suggested by Miles \& Huberman (1984:28; 1994:18), a conceptual framework as depicted in Figure 1 was developed for purposes of the study. 
Figure 1: A conceptual framework for examining the aims of Human Resources Management and Industrial Psychology teaching departments, and career options for which their students are equipped

23 Institutions

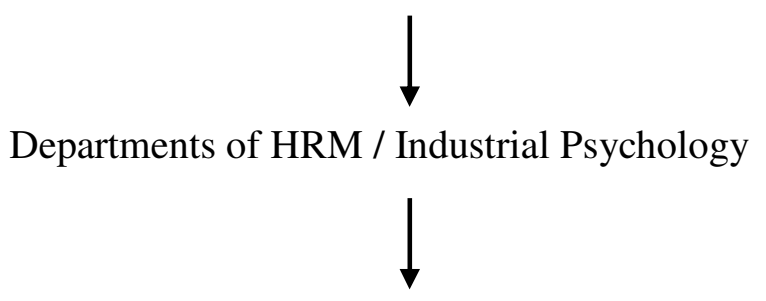

Web Pages

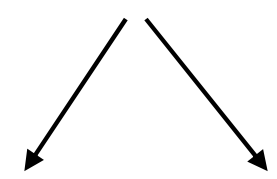

Programme/Course: Aim

Career options

The data collected from each of the cases were used to build a cross-case compilation which displayed the position of each case regarding the aim of the programme/course and possible career options after graduation. Miles and Huberman (1994:17) refer to these cross-case displays as meta-matrices. They are master charts that gather descriptive data from each of the individual cases in a standard format. Table 1 illustrates the result of this step.

Table 1: A compilation of the extracts of the web page information of some of the departments that teach Human Resources Management and Industrial Psychology

\begin{tabular}{|c|l|l|}
\hline $\begin{array}{c}\text { Case } \\
\text { No }\end{array}$ & \multicolumn{1}{|c|}{ Aim } & \multicolumn{1}{c|}{ Career opportunities } \\
\hline 1 & $\begin{array}{l}\text { To equip students with the competencies to } \\
\text { master the core Human Resources processes and } \\
\text { practices }\end{array}$ & $\begin{array}{l}\text { Personnel Administration, } \\
\text { Personnel Officer, Industrial } \\
\text { Relations Officer, Training } \\
\text { Officer, Union organiser, Labour } \\
\text { official or Inspector, Recruitment } \\
\text { Specialist }\end{array}$ \\
\hline
\end{tabular}




\section{Table 1 continued}

\begin{tabular}{|c|c|c|}
\hline $\begin{array}{l}\text { Case } \\
\text { No }\end{array}$ & Aim & Career opportunities \\
\hline 2 & $\begin{array}{l}\text { Human Resources Managers provide the specialised } \\
\text { services needed by the management members to make the } \\
\text { most effective use of the human resources within an } \\
\text { organisation. }\end{array}$ & $\begin{array}{l}\text {... Graduates usually start as human } \\
\text { resources officers and then become } \\
\text { managers after gaining experience. } \\
\text { They may work in the general } \\
\text { personnel field, or specialise in } \\
\text { specific aspects of personnel } \\
\text { management, training or industrial } \\
\text { relations. }\end{array}$ \\
\hline 3 & $\begin{array}{l}\text { Industrial/Organisational psychology is a special social } \\
\text { science discipline within the broad field of psychology that } \\
\text { studies human behaviour in the work environment. } \\
\text { Application of the method, facts and principles of the } \\
\text { science of behavioural processes to study the people at } \\
\text { work. The aims of the discipline are knowledge and } \\
\text { understanding of human work behaviour and to improve } \\
\text { work performance. }\end{array}$ & $\begin{array}{l}\text { Human Resources Manager, } \\
\text { Industrial Psychologists, Lecturer, } \\
\text { Human Resources Officer, Industrial } \\
\text { Relations Consultant, Administrator. }\end{array}$ \\
\hline 4 & $\begin{array}{l}\text { Industrial Psychology, as an applied behavioural science, } \\
\text { focuses on the explanation of the development of human } \\
\text { behaviour in the work environment. In every organisation } \\
\text { people are important whether in the capacity of employee, } \\
\text { manager or consumer. However no organisation can be run } \\
\text { without other resources such as raw materials, capital, } \\
\text { equipment etc. }\end{array}$ & $\begin{array}{l}\text { Industrial Psychologist, Personnel } \\
\text { Manager or Labour Relations in the } \\
\text { Public Service }\end{array}$ \\
\hline 5 & $\begin{array}{l}\ldots . . \text { In this regard pioneered the establishment of an } \\
\text { academic capacity to respond to this challenge and elevated } \\
\text { the field of Human Resources Management. ... } \\
\text { A Human Resources Practitioner deals with people in an } \\
\text { organisation }\end{array}$ & Not indicated \\
\hline 6 & $\begin{array}{l}\text { The mission of the Department of Human Resources } \\
\text { Management is to provide the most appropriate career } \\
\text { education in two core areas of human resources } \\
\text { management and organisational behaviour. }\end{array}$ & No usable/relevant information \\
\hline 7 & $\begin{array}{l}\text {.... a Human Resources Manager has to meet the } \\
\text { organisation's requirements of an effective work force, } \\
\text { whilst simultaneously being concerned with expectations of } \\
\text { employees .... }\end{array}$ & No usable/relevant information \\
\hline 8 & $\begin{array}{l}\text { This degree will equip you to become a Human Resources } \\
\text { practitioner in an organisation. }\end{array}$ & Human Resources Practitioner \\
\hline 9 & No usable/relevant information & $\begin{array}{l}\text { Consultant in private practice } \\
\text { (Human Resources Management); } \\
\text { Manager: Corporate Social } \\
\text { Responsibility Projects; General } \\
\text { Manager; Promotion Manager; } \\
\text { Human Resources Manager; } \\
\text { Entrepreneur; Labour Relations } \\
\text { Consultant. }\end{array}$ \\
\hline
\end{tabular}


Table 1 continued

\begin{tabular}{|c|l|l|}
\hline $\begin{array}{c}\text { Case } \\
\text { No }\end{array}$ & \multicolumn{1}{|c|}{ Aim } & \multicolumn{1}{|c|}{ Career opportunities } \\
\hline 10 & $\begin{array}{l}\text { To equip students with relevant knowledge and skills to } \\
\text { enable them to staff the organisation, design and analyse } \\
\text { jobs, develop employees, identify approaches to improve } \\
\text { performance, reward employees and maintain sound labour } \\
\text { relations. }\end{array}$ & $\begin{array}{l}\text { Industrial Psychology - } \\
\text { undergraduate qualification may lead } \\
\text { to employment in industrial relations, } \\
\text { ergonomics, marketing and } \\
\text { consultancy. }\end{array}$ \\
\hline 11 & $\begin{array}{l}\text { Equip learners with the necessary skills and knowledge that } \\
\text { would provide a solid foundation for a career in the field of } \\
\text { general human resources management }\end{array}$ \\
$\begin{array}{l}\text { To promote the understanding, creation, skills and values } \\
\text { relevant and critical to the proper functioning and } \\
\text { development of the HRM and LR function in the new South } \\
\text { Africa, thereby enhancing quality of organizational } \\
\text { effectiveness and national development. }\end{array}$ & \\
\hline
\end{tabular}

\section{Discussion}

\section{Primary data: Interviews}

Based on the information obtained by interviews, human resources practitioners could assist SMMEs with the following services:

- Establishing human resources requirements; unsuccessful entrepreneurs fail to plan and set goals for their enterprises;

- Job analysis: job descriptions and job specifications;

- Recruitment and induction of personnel;

- Application of labour laws and maintaining good labour relations; employment contracts;

- Training and development of employees to improve skills and efficiency;

- Compensation management: establishing a wage and salary structure;

- Ensuring workplace health and safety;

- Introducing employee motivation techniques;

- Introducing performance management systems; and

- Designing human resources information systems.

\section{Secondary data analysis}

As indicated above, only 21 institutions of higher learning were subjected to examination. An investigation into the aim or objective of the human resource training programmes or courses taught by the different tertiary institutions showed only ten with usable or relevant information which had a bearing on the aim of the programmes or courses offered. Careful analysis of the ten cases revealed that none of the programmes or courses, according to their respective web pages, is directed at equipping students for entrepreneurship or becoming an entrepreneur. 
Out of the 21 cases, only 7 had usable or relevant information which indicated possible career options for which students were equipped through the training offered by the respective departments.

Only one university clearly mentioned the career option of an entrepreneur. This institution is also the only case in which the possibility of a career as a human resources consultant in private practice is clearly indicated.

Cases 5, 6 and 17 indicated the career option of industrial psychologist, but from the available information it is not clear whether this refers to self-employment in private practice or as an employee in a corporate environment.

\section{Limitations of the study}

The current study is limited only to South African tertiary institutions. The scarcity of literature on this topic limits the findings of the study to comparative studies.

\section{Implications for management}

Departmental management and faculty management should be aware that web pages serve as "display windows" of tertiary institutions, and the information advertised should be carefully considered. Furthermore the introduction of an entrepreneurial perspective to their teaching in many disciplines could make an additional career option, namely that of entrepreneur, available to their students.

\section{Recommendations for South Africa}

The following are a few recommendations to improve this apparent lack of an entrepreneurship approach in the training of human resources practitioners and industrial psychologists of the future.

Human Resources Management courses generally consist of various free-standing modules such as economics, accountancy, business management, statistics, marketing, industrial psychology, and human resources management, to name but a few. Unfortunately students are currently not taught how to apply many of these modules in a situation where they are self-employed in their own businesses. For example, students are seldom taught how to market their own business or its services, or how to apply for finance for their own business or what the effect of interest rate changes will be on the business financing and demand for products and services. Such important factors which impact on business are conspicuously absent from their training.

If the above skills are taught to students they are often not able to link the various pieces of knowledge acquired in the different subject disciplines into an integrated whole. It is encouraging that the current secondary school system provides for various themes which are then discussed within the different learning areas. In a particular year, for example, 
one of the themes is festivals. Festivals are then discussed from a historical, a human and social science perspective, as well as from economic and management sciences and mathematical and scientific perspectives. It is therefore argued that similar models should be followed at tertiary educational institutions in order to obtain an integrated entrepreneurial perspective of all the underlying subject areas.

Another suggestion for improving the current tertiary teaching situation is to encourage academics to obtain more practical experience and knowledge of small business and selfemployment. The over-emphasis on academic research output is perhaps more suited to first-world environments, where massive unemployment and poverty are not such a pressing issues as is the case in developing countries such as South Africa.

In view of the above, it could perhaps be argued that the deficiency in entrepreneurial training at tertiary level could be remedied by the introduction of an additional interdisciplinary module such as: How to become self-employed in your discipline. The danger of this approach is that this could easily be viewed as just another additional module in an already overcrowded curriculum and thus totally fail in its aim. It is therefore proposed to rather encourage lecturers to introduce an entrepreneurial and selfemployed perspective in their teaching, based on their own experience and knowledge of entrepreneurship and self-employment.

\section{Directions for future research}

Future research could investigate the views of departmental staff on including entrepreneurship and self-employment as aims of their programmes, and offering the career options of entrepreneurship and self-employment. Past graduates, as the consumers of these programmes, could be questioned on their experience of entrepreneurship and career options after the courses that they completed.

\section{Conclusion}

As indicated above, South Africa is faced with an unacceptable unemployment rate. Entrepreneurs and SMMES can contribute to providing job opportunities and assist in counteracting the negative consequences of high unemployment.

Based on the information obtained from the web pages displaying the curricula of the various Human Resources and Industrial Psychology departments surveyed in this study, only one university gives entrepreneurship as a clearly declared aim for its curriculum. Only one of the seven cases with usable information on career opportunities for graduates makes any mention of the career option of entrepreneur.

These findings are very disappointing considering the huge need for entrepreneurs in South Africa. Education in entrepreneurship could unlock alternative career options for students in Human Resources Management and Industrial Psychology and equip them for providing services to SMMEs to help ensure their success. 


\section{References}

Barker, F. 2003. The South African labour market. $4^{\text {th }}$ ed. Pretoria: Van Schaik.

Creswell, J.W. 1998. Qualitative inquiry and research design: choosing among five traditions. Thousand Oaks, Calif: Sage.

Christianson, D. 2005. Can entrepreurship save South Africa's youth? Enterprise, June 30: 12.

Dana, L-P. 1993. An international survey of entrepreneurship education. Journal of Enterprising Culture, 1(1):67-92.

Du Plessis P.G. 1996. Applied business management: an introductory survey. Pretoria: Kagiso Tertiary.

Finnemore. M. 2002. Introduction to labour relations in South Africa. $8^{\text {th }}$ ed. Durban: Butterworths.

Grobler, P., Wärnich, S., Carrell, M.R., Elbert, N.F. \& Hatfield, R. 2006. Human resource management in South Africa. $3^{\text {rd }}$ ed. London: Thompson Learning.

ISEDS (Integrated Small-Enterprise Development Strategy). 2005. Department of Trade and Industry. [Online] Available from: http://www.thedti.gov.za.html [Accessed: 2007-09-14].

Klofsten, M. 2005. New venture ideas: an analysis of their origin and early development. Technology Analysis \& Strategic Management, 17(1):105-119.

Ladzani, W.M. \& Van Vuuren, J.J. 2002. Entrepreneurship training for emerging SMMEs in South Africa. Journal of Small Business Management, 40(2):154-161.

Liedholm, C. 2002. Small firm dynamics: evidence from Africa and Latin America. Small Business Economics, 18:227-242.

Lincoln, Y. \& Guba, E. 1985. Naturalistic inquiry. Beverly Hills, CA: Sage.

Luiz, J. 2002. Small business development, entrepreneurship and expanding the business sector in a developing economy: the case of South Africa. The Journal of Applied Business Research, 8(2):53-68.

Miles, M. B. \& Huberman, A. M. 1984. Qualitative data analysis: a source book of new methods. London: Sage.

Miles, M. B. \& Huberman, A. M. 1994. Qualitative data analysis: a source book of new methods. London: Sage.

Miller, K. 2007. Teaching musicians to be entrepreneurs. Business Week Online, 03-29-2007:20. [Online] Available from: http//0-web.ebscohost.com.innopac.up.ac.za/ehost/delivery?vid=6\&hid=107\&hid=107 \&sid=38/html [Accessed: 2008-02-07] .

Nel, P.S., Van Dyk, P.S., Haasbroek, G.D., Schultz, H. B., Sono. T. \& Werner, A. 2004. Human resource management. $6^{\text {th }}$ ed. Cape Town: Oxford University Press.

Pahn, L. 1993. Small business management and entrepreneurship. Cape Town: Maskew Miller Longman.

Punch, K. 2005. Introduction to social research: quantitative and qualitative approaches. 3rd ed. London: Sage. 
Republic of South Africa. 1996. Growth, employment and redistribution: a macro-economic strategy (Gear strategy). Pretoria: Government Printer.

Republic of South Africa. 1998. Creating jobs, fighting poverty: an employment strategy framework. Government Gazette. 3 July 1998.

SABG (South African Business Guidebook). 2006/2007. Small, medium and micro entrepreneurs. South Africa Business Guidebook. [Online] Available from: http//www.journals.co.za/ej/ejour_ws_sabg.html [Accessed: 2008-02-07].

Simoncelli, F. 2007. Verbal telecommunication with author on 10 September. Pretoria. (Notes in authors' possession.)

South African Qualifications Authority. 2007. Registered Human Resources Qualifications. [ Online] Available from: http://reqs.saqa.org.za.html [Accessed: 2007-09-21].

StatsSA (Statistics South Africa). 2007. Labour Force Survey, March 2007. [Online] Available from http://www.statssa.gov.za/publications/statkeyfindings.asp?PPN=P0210 \&SCH=4006.html [Accessed: 2007-11-05]

Tchouvakhina, M. 2004. KfW and the promotion of entrepreneurship training in Germany. Higher Education in Europe, 29(2):233-237.

Terblanche, B. 2007 Chop-chop gets the axe: Mail and Guardian Comment. Mail and Guardian, September 7 to $-13: 7$.

Uhlander, L. \& Thurik, R. 2007. Postmaterialism influencing entrepreneurial activity across nations. Journal of Evolutionary Economics. [Online] Available from: http://0-wwwspringerlink.com/html [Accessed: 2007-08-08].

Van Aardt, I. \& Van Aardt, C. 1997. Enterprise and new venture management. Johannesburg: International Thompson Publishing.

Van der Walt, J.L. 2007. Verbal telecommunication with author on 9 September. Pretoria. (Notes in authors' possession.)

Van Eeden, S., Viviers, S. \& Venter, D. 2003. A comparative study of selected problems encountered by small businesses in the Nelson Mandela, Cape Town and Egoli metropoles. Management Dynamics, 12(3):13-23.

Von Broembsen, M. 2006. Losing the entrepreneurship battle. Business Day, 15 March: 13.

Von Broembsen, M., Wood, E. \& Herrington, M. 2005. Global Entrepreneurship Monitor: South African Report. [Online] Available from: http://www3. babson.edu/ Newsroom/Releases/globalgem11206 release .cfm - 38k -html [Accessed: 2008-02-01].

Williamson, I.O. 2000. Employer legitimacy and recruitment success in small businesses. Entrepreneurship Theory and Practice, 25(1):27-42.

Zikmund, W.G. 2003. Business research methods.7th ed. London: Thomson. 